\title{
Challenges and strategies of postgraduate students in online learning during the Covid-19 pandemic
}

\author{
Anang Fathoni *, Heri Retnawati \\ Universitas Negeri Yogyakarta. Jl. Colombo No. 1, Karangmalang, Yogyakarta 55281, Indonesia \\ * Corresponding Author. E-mail: anangfathoni.2019@student.uny.ac.id
}

Received: 6 January 2021; Revised: 28 January 2021; Accepted: 18 March 2021

\begin{abstract}
The ongoing online learning during the Covid-19 pandemic has become a separate catalyst for the development of education that utilizes technology in the current industrial 4.0 era. However, on the other hand, there are still many gaps in online learning during the Covid-19 pandemic. This research study aims to (1) explore the experiences of postgraduate students in online learning; (2) describe the negative impacts and barriers to online learning, along with strategies for dealing with them; and (3) observe the potential that emerges in the future after the Covid-19 pandemic can be overcome. This research is qualitative research with a type of case study. Data were collected through open questionnaires and interviews with participants of 30 postgraduate students of the Primary education study program, Yogyakarta State University. Data analysis was accomplished by examining themes and sub-themes in each topic discussed, then determining the correlation between the sub-themes to conclude. The results show that students have varied experiences throughout online learning during the Covid-19 pandemic. In addition, students also gain negative physical and psychological impacts, get obstacles concerning data reception, gadgets, interaction with lecturers, independent study, and learning activities during the Covid-19 pandemic. However, students also still have various strategies in dealing with the obstacles and negative impacts of Covid-19. Finally, online learning during the Covid-19 pandemic is giving potential as well as negative things in the future once it is resolved. Keywords: covid-19, obstacles, strategy, online learning, postgraduate students
\end{abstract}

How to Cite: Fathoni, A., \& Retnawati, H. (2021). Challenges and strategies of postgraduate students in online learning during the Covid-19 pandemic. Jurnal Prima Edukasia, 9(2), 233247. doi:https://doi.org/10.21831/jpe.v9i2.37393

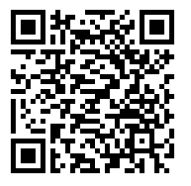

\section{Introduction}

SARS-Cov-2 is a new variant of the virus that first appeared in Wuhan (Hubei Province), China, on December 31, 2019 (Lee, 2020). This virus is often referred to as COVID-19 or Coronavirus. Based on WHO data on January 28, 2021, there were 100,200,107 positive cases worldwide, 2,158,761 deaths, and an increase in positive cases a day, reaching 335,561 new cases (World Health Organization, 2020). Meanwhile, in Indonesia, the number of positive cases on the same date reached 1,037,993, with 29,331 death and 842,122 people recovered (Satuan Tugas Penanganan Covid-19, 2020). The appearance of Covid-19 certainly raises a sense of anxiety because humans are required to adapt to habits through the physical distancing protocol. Psychological pressure emerges from within everyone around the world (Duan \& Zhu, 2020). For students, the presence of Covid-19 also affects mental health in the form of student anxiety (Rakhmanov \& Dane, 2020; Wang \& Zhao, 2020). The existence of this new habit has an impact, one of which is in the world of education, which makes learning must go through a physical distancing protocol with an online system (Purwanto et al., 2020; Syah, 2020). One of the government's efforts to control the spread of Covid-19 is by closing schools (Arlinwibowo et al., 2020). Learning with the digital format is the most relevant and an excellent alternative to be used during the Covid-19 pandemic (Daniel, 2020).

Online (Daring) learning stands for learning within the network (Sudarsana et al., 2020; Yuliani et al., 2020) or often referred to as online learning. The transition from face-to-face to distance learning through an online system is an effort to reduce the risk of the spread and transmission of Covid-19 (Yuliani et al., 2020). Distance learning, which is currently taking place at all levels of education, including at the college level, has become a catalyst for the development of education that utilizes technology in the industry 4.0 era. The use of technology and information is key in the Covid-19 
Jurnal Prima Edukasia, 9 (2), 2021 - 234

Anang Fathoni, Heri Retnawati

pandemic in the world of education (Herliandry, Nurhasanah, Suban, \& Heru, 2020). E-learning during the covid-19 period was an appropriate crisis response measure (Murphy, 2020). Based on the circular letter of the Minister of Education and Culture of the Republic of Indonesia No. 4 of 2020 concerning the implementation of education policies in the emergency period of the spread of Covid-19 in point number two provides provisions for the learning process to be carried out at home through online (distance learning) learning (Menteri Pendidikan dan Kebudayaan RI, 2020). Therefore the face-to-face system transition to a distance learning system becomes a form of obligation to reduce the risk of covid19 transmission (Yuliani et al., 2020) starting from kindergarten to college level.

At the college level, lecturers certainly have the responsibility of designing learning and formulating learning strategies by utilizing various learning sources under any conditions (Pratiwi, 2019). Lecturers must improve IT skills and increase the variety of learning using technology. Previous research stated that educators during the Covid-19 pandemic needed technological knowledge, pedagogical knowledge, and content knowledge in online teaching (Makawawa et al., 2021). One of the learning characteristics that lecturers need to focus on during the pandemic is access to learning resources that make it easier for students to study anywhere and anytime and access communication and information technology media (Suparman, 2014). Likewise, the effectiveness of learning can be increased by educators (lecturers) through increasing insights concerning what are the effective learning strategies from the point of view of students and how students utilize them (Tomes et al., 2011). Methods and learning media factors are also crucial in learning effectiveness (Jalinus \& Ambiyar, 2016). Three essential elements of online distance learning are educators, learners, and platforms (Zhu et al., 2020). The regular use of online technology (Dabbagh, 2007), the advancement of the internet (Alqurashi, 2019; C. S. Chang et al., 2014), and technology skills (Jan, 2015) are essential factors in the implementation of online distance learning at the College level. Also, critical components that can support online learning effectiveness for lecturers and students are discursive, adaptive, interactive, and reflective (Oktavian \& Aldya, 2020). Effective online learning from a learner's perspective can be seen from students' positive attitude towards online learning, learning readiness, independence, time management, and implementation strategies to eliminate learning distractions (Erarslan \& Arslan, 2020; Sadikin \& Hamidah, 2020).

However, the shift from a face-to-face environment to a fully online environment through distance learning is certainly a new challenge that is not easy (Scull et al., 2020) and creates confusion (Jhon et al., 2020). Previous research has shown that online distance learning can lead to stress due to difficulties in time management (Ghiasvand et al., 2017; Tseng et al., 2019), uncertainty concerning the research/ writing process synchronically with insufficient support from supervisors (Silinda \& Brubacher, 2016), and eye strain (Octaberlina \& Muslimin, 2020). Apart from that, distance learning cannot meet the learning needs as much as face-to-face (Best \& Conceição, 2017; Cao \& Sakchutchawan, 2011). There are fewer interactions between students and peers and educators/tutors than during the face-to-face (Tichavsky et al., 2015). Whereas the relationship and communication created between students and educators can increase involvement in the learning process (Zeng et al., 2016), reduce anxiety (Talidong \& Toquero, 2020), and build emotional patterns that can provide cognitive support for students (Chatzara et al., 2016). Also, another problem is the readiness of lecturers to prepare online material, which is not only online conventional course material, but also how to ensure the achievement of learning outcomes (Mulawarman, 2020), maintaining student learning attention, arranging class discussions, online communication, and recognizing and mastering various online learning platforms (C.-L. Chang \& Fang, 2020).

The inhibiting factors for distance learning for lecturers and students are the students' weak independent learning ability (C.-L. Chang \& Fang, 2020), the use of a higher quota than before the Covid-19, a less than optimal explanation (Jariyah \& Tyastirin, 2020), poor network/internet connection (Noer et al., 2021; Octaberlina \& Muslimin, 2020). Even though at this time, the existence of quota assistance from the government and free services provided from several providers (Budiansyah, 2020) can reduce the burden of spending on quotas for educators and students, however, no matter how good the access to education, without the support of a good, reliable internet network, it will have an impact on less than optimal learning (Arizona et al., 2020). Based on the complexity of the problems that arise and the lack of exploration of the experiences of postgraduate students during the Covid-19 pandemic, this article aims to (1) explore the experiences of postgraduate students in online learning; (2) describe 
Jurnal Prima Edukasia, 9 (2), 2021 - 235

Anang Fathoni, Heri Retnawati

the negative impacts and barriers to online learning, along with strategies for dealing with them; and (3) see the potential that emerges in the future after the Covid-19 pandemic can be overcome.

\section{Methods}

This research is qualitative research with a type of case study. This research was conducted online at the Universitas Negeri Yogyakarta on 9-27 October 2020. Participants in this study were postgraduate students of the Primary education study program with 30 students who had carried out online learning for one semester. Thus the authors chose students from class 2019 semester three as respondents. Determination of research subjects is using the purposive sampling technique by considering the objectives of the study.

Data was collected online through an open questionnaire with Google Form and interviews via WhatsApp. It was initially using an open questionnaire via Google Form to acquire general problems. Furthermore, individual interviews were conducted to expand the information. The materials for open questionnaires and interviews included (1) exploration of student experiences in online learning; (2) negative impacts, obstacles, and strategies for dealing with them; and (3) the potential that emerges in the future after the Covid-19 pandemic can be overcome. Researchers are the main instrument in this study. Data from open questionnaires and interviews were further reduced. Then, the reduction data was presented in tabular form, and sub-themes were searched. The analysis was carried out using Bogdan \& Biklen model by reducing and searching for sub-themes and relationships between sub-themes (Bogdan \& Biklen, 1982).

Open questionnaires and interviews were scheduled according to each respondent's free time. Students who participated in this study agreed to become respondents without coercion. Researchers convey all data submitted to researchers only used in this study. All participant identities are kept confidential. Matters related to participants' responses to open-ended questions and interviews are kept confidential and do not affect participants' future fate.

\section{Results and Discussion}

Results

The results of this study are divided into three main topics concerning (1) exploration of postgraduate student experiences in online learning; (2) negative impacts, obstacles, and strategies for dealing with them; and (3) the potential that emerges in the future after the Covid-19 pandemic can be overcome. The research results are then reduced, and searching for sub-themes on the themes found in each topic discussed. Furthermore, the sub-themes are linked to each other to acquire a conclusion on each topic. Each of the topics discussed is presented in more detail in the following discussion.

Exploration of the experience of postgraduate students

The topic of exploring the experiences of postgraduate students in online learning was found in six themes to understand postgraduate students' online learning experiences during the Covid-19 pandemic. The six themes are (1) the use of gadgets and the internet; (2) learning activities; (3) support for the learning environment; (4) techniques to optimize learning; (5) student-lecturer relationship; and (6) student research during the Covid-19 pandemic. Each of the themes obtained is presented as follows.

\section{The use of gadgets and the Internet}

All students stated that they had the facilities needed for online learning, such as (1) gadgets in the form of smartphones/tablets and laptops/personal computers; and (2) internet from various types of providers in Indonesia such as Indosat, Three, Telkomsel, XL, and Indihome (WiFi). Based on data analysis results on the use of gadgets and the internet from students during the pandemic period, three sub-themes were discovered as presented in Table 1.

The first key for online learning can be carried out: the fulfillment of facility needs consisting of gadgets and the internet. Without this, online learning will not be possible. Students convey that gadgets and the internet are considered to be the main solutions in online learning. Students also said that they were accustomed to using technology in online learning either before the Covid-19 and during the Covid-19 emergence. However, two students said a need for adaptation to technology in the early days of changing from face-to-face to online. 
Jurnal Prima Edukasia, 9 (2), 2021 - 236

Anang Fathoni, Heri Retnawati

Table 1. Reduction result concerning The Use of Gadgets and Internet

\begin{tabular}{cll}
\hline No. Sub-theme & Correlation between Sub-theme \\
\hline 1. & $\begin{array}{l}\text { Gadgets and the Internet are considered to be the main solutions in } \\
\text { online learning }\end{array}$ & $\begin{array}{l}\text { Students are used to using } \\
\text { technology in online learning, }\end{array}$ \\
2. Students have become accustomed to using technology either before & $\begin{array}{l}\text { and the intensity of use has } \\
\text { increased after the emergence of }\end{array}$ \\
the Covid-19 and during the Covid-19 pandemic. & $\begin{array}{l}\text { The intensity of using technology increased after the emergence of } \\
\text { Covid-19. }\end{array}$
\end{tabular}

The thing that distinguishes between before and during the appearance of Covid-19 is the intensity of technology use that increased after the emergence of Covid-19. Before the Covid-19, internet use was about finding information about education and references to do assignments or study. After the emergence of Covid-19, internet usage became more frequent. Several platforms that were never used before or were rarely used became frequent, such as zoom, google meet, be-smart (e-learning from campus), google classroom, et cetera.

\section{Learning Activities}

Students' experience in learning activities during the Covid-19 pandemic showed that studying during the Covid-19 period made students more independent in learning. This was due to the reduction in interaction between students and other people to reduce the number of infections from Covid-19; thus, students tend to perform all activities independently, either at home and in their boarding house. Based on data analysis results on student learning activities during the pandemic period, five sub-themes were found as presented in Table 2.

Table 2. Reduction Results related to Learning Activities

\begin{tabular}{cll}
\hline No. & Sub-theme & Correlation between Sub-theme \\
\hline 1. & Becoming more independent in learning & $\begin{array}{l}\text { Online learning makes students } \\
\text { 2. }\end{array}$ \\
$\begin{array}{l}\text { Obtaining reference sources for working on assignments from } \\
\text { ebooks, journal articles, printed books that are owned, and online } \\
\text { libraries }\end{array}$ & $\begin{array}{l}\text { and makes students have to } \\
\text { manage time to study with other } \\
\text { activities }\end{array}$ \\
3. & Setting specific times for doing assignments and studying. & \\
4. & $\begin{array}{l}\text { The exact time to do assignments is at night because it increases } \\
\text { concentration. }\end{array}$ & \\
5. & Trying to do tasks on time directly.
\end{tabular}

Students explained that they began to set specific times for doing assignments and studying. The study time determination of students varies, but what is certain is that students say that studying at night makes students more concentrated. Also, resting is important in learning and doing assignments because without having a break, it will make the mind clogged up and instead make the learning process and work on assignments less than optimal.

\section{Support for the Learning environment}

The results of the analysis on the support of the learning environment from students show that the support of the learning environment was influenced by three things, namely (1) the facilities owned; (2) support from family; and (3) a quiet and comfortable learning environment. The results of data analysis can be seen in Table 3 as follows.

Table 3. The results of reduction related to the support of learning environment

\begin{tabular}{cll}
\hline No. Sub-theme & Correlation between Sub-theme \\
\hline 1. Having facilities in the form of gadgets and the internet & $\begin{array}{l}\text { Support for the learning } \\
\text { environment is influenced by three }\end{array}$ \\
connection which are the main means to support online learning & $\begin{array}{l}\text { Family support can make students feel comfortable in online } \\
\text { things, namely the facilities owned, } \\
\text { support from family, and a quiet } \\
\text { and comfortable learning } \\
\text { environment }\end{array}$ \\
3. A quiet study environment & Designing the room to keep it comfortable
\end{tabular}

As has been discussed in "the use of gadgets and the internet" theme, it shows that facilities in the form of gadgets and the internet connection are the main means of supporting online learning. The absence of gadgets and the internet can hinder online learning. Also, family support is essential in online 
Jurnal Prima Edukasia, 9 (2), 2021 - 237

Anang Fathoni, Heri Retnawati

learning because online learning is mostly done at home. Inadequate home facilities can hinder online learning. Therefore, some students choose to return to boarding houses because the internet connection at home is inferior. This was conveyed by students 11 and 16 .

"At home, the environment is less supportive, and the problem is internet connection is poor. However, when in the boarding house, it goes smoothly. Especially now that we received internet quota assistance from the campus." (Student 11)

"At home, it is not very supportive, especially the signal reception. But in the boarding house, God willing, it is supportive, because there is WiFi." (Student 16)

Also, a quiet learning environment and a room conditioned according to students' wishes make it more comfortable for them to participate in online learning. Of course, each student has a difference in finding the comfort obtained by conditioning their room. Some students said that to achieve this comfort, it could be obtained by adjusting the study lamp; thus, it provides adequate irradiation, electricity supply for electronic devices, fans, mini-libraries, $\mathrm{WiFi}$, et cetera.

\section{Techniques to Optimize Learning}

Students have a variety of techniques that can be used to optimize learning during the Covid-19 pandemic. The results of data analysis show that there are six sub-themes as presented in Table 4.

Table 4. Reduction Results related to Techniques to Optimize Learning

\begin{tabular}{|c|c|c|}
\hline No. & Sub-theme & Correlation between Sub-theme \\
\hline 1. & $\begin{array}{l}\text { Eliminate all distractions from smartphones by silencing cellphones } \\
\text { and avoid toxicity from time-consuming social media }\end{array}$ & $\begin{array}{l}\text { Students have a variety of } \\
\text { techniques that can be used to }\end{array}$ \\
\hline 2. & Self-Rewarding for certain achievements & optimize learning during the \\
\hline 3. & Setting reminders for mandatory activities & Covid-19 pandemic \\
\hline 4. & Setting the priority scale & \\
\hline 5. & $\begin{array}{l}\text { Reading, rewriting, criticizing, elaboration of knowledge, forming } \\
\text { arguments, and brainstorming. }\end{array}$ & \\
\hline 6. & Adding daily routine by learning from youtube and webinars & \\
\hline
\end{tabular}

Students have their own methods in optimizing their learning during the Covid-19 pandemic. Some students have something in common, some are different, and some still have not found an effective technique. Students' similarity was by setting a priority scale through a to-do list on the work and tasks that must be done. These activities made students felt more systematic when doing assignments, studying, or doing other activities. Some students also tried to eliminate all distractions from smartphones by silencing their cellphones and avoiding toxicity from social media, which takes up time. Avoiding distractions is very necessary to increase concentration in studying and doing assignments. Other students also conveyed the distraction of their ineffective learning method because they were often exposed to distraction from their gadgets. This is as stated by the following students.

“......The problem is the intention to work because there are many temptations such as from YouTube and playing online games" (Student 6 )

"Every morning and night I familiarize myself to opening assignments, but in the end, I open YouTube and webtoon" (Student 25)

Students' other techniques are by rewarding themselves for certain achievements, adding to routines by learning from youtube and webinars, and reading, rewriting, criticizing, elaborating knowledge, forming arguments, and brainstorming with peers. However, there are still students who have not found a suitable or effective method for doing assignments or studying. The following students conveyed this.

"I am still trying to find an effective self-study method because I have not found it yet" (Student 3)

There is no specific method. I am still a deadliner. In my opinion, sometimes it is effective, sometimes it is not. However, for scientific papers, it is proven ineffective" (Student 11)

\section{Students-Lecturers Relationship}

The results of data analysis on the theme of student-lecturer relationship obtains two conclusions, i.e. (1) a good relationship between students and lecturers will help students study during the Covid-19 
Jurnal Prima Edukasia, 9 (2), 2021 - 238

Anang Fathoni, Heri Retnawati

pandemic; and (2) The poor student-lecturer relationship will hamper the study process during the Covid-19 pandemic.

A good relationship between students and lecturers is indicated by (1) lecturer's willingness to guide students in doing their assignments and research; (2) lecturers who provide feedback and reflection on learning; (3) lecturers who understand the condition of their students and understand the problems their students have; and (4) supervising lecturer who provides support and are responsive to student assignments make students not feel worried. The following students conveyed this.

"I am not too worried because the supervising lecturer is also very nice.... usually the lecturer always asks about difficulties and gives opportunities for students to give questions "(Student 12)

"The interaction that exists with the lecturers is good because the lecturers understand the condition of students and often understand the problems they have." (Student 17)

"The interpersonal relationship between the lecturer and me can be said to be good. Sometimes I do not hesitate to ask questions/invite discussions to lecturers, especially in cases related to daily life that I encounter in the world of education .... "(Student 21)

The weak relationship between students and lecturers will hinder the student learning process. The weak relationship is indicated by (1) lecturers who respond slowly, hindering students from doing assignments and research; (2) there are still lecturers who only rely on assignments without reflection; (3) the supervising lectures is difficult to contact; (4) slow response from lecturers makes consultation less effective, and (5) Too demanding supervising lecturer is actually making students uncomfortable. The following students conveyed this.

"Learning process is very ineffective because lecturers do not provide feedback so we do not know whether what we are doing and understand is right or wrong." (Student 10)

"There are still lecturers who rarely reflect, the only communication that exists is assigning assignments and assignments submission" (Student 13)

"Not as smooth as during face to face. Especially about thesis problems, lecturers are slow to respond. " (Student 16)

\section{Student Research during the Covid-19 pandemic}

Data analysis results show that student research during the Covid-19 pandemic could not be carried out optimally and makes students worried. This less than optimal research is characterized by several things such as (1) less freedom to take initial data in research; (2) the research permit issued for a longer time; (3) online consultation is not optimal because sometimes students feel uncomfortable when they ask many questions; and (4) the process of finding references becomes longer because they cannot go to the library. Meanwhile, students' concerns refer to technical matters in research, such as the validation process, processing research permits, and collecting data in the field. Also, students are worried about not being able to complete their research on time.

\section{Negative impacts, obstacles, and strategies to deal with them}

The topic of negative impacts and obstacles that arise in online learning is found in five themes and strategies for dealing with them. The five themes are (1) psychological condition; (2) physical condition; (3) signal reception and gadget conditions; (4) learning environment conditions; and (5) conditions of learning activities. The negative impact of Covid-19 is on psychological and physical conditions, while the obstacles appear in signal reception, gadgets, learning environments, and activities in learning. Each of the themes obtained is presented as follows.

\section{Psychological condition}

Online learning during the Covid-19 pandemic affected the psychological condition of students. The results of the analysis of the psychological condition of the students can be observed in Table 5 .

Students conveyed that the level of boredom was higher during online learning than face-to-face. This was because the assignment load was higher than face-to-face, monotonous activity in front of a laptop or smartphone was continuously carried out with a higher intensity than face-to-face, and reduced direct interaction between fellow students. Students also conveyed that they felt anxious about the uncertainty of research and data collection ethics. Basically, technical matters such as permits, expert 
Jurnal Prima Edukasia, 9 (2), 2021 - 239

Anang Fathoni, Heri Retnawati

validation, and data collection ethics still need to be clarified and disseminated directly to students. Then, some students explained that they became insecure when asking questions. Furthermore, students felt more easily bored, overthinking, lazier, and less enthusiastic because the home culture was different when they were in a campus environment, which was intended for the learning process. Some of these findings show that student motivation decreased during the Covid-19 pandemic.

Table 5. Reduction Results related to Psychological Conditions

\begin{tabular}{cll}
\hline No. & Sub-theme & Correlation between Sub-theme \\
\hline 1. & Boredom levels are higher during online learning than in face-to-face. & $\begin{array}{l}\text { Online learning affects the } \\
\text { psychological condition of }\end{array}$ \\
2. & Decreased learning motivation & There is a feeling of anxiety about the research's uncertainty and the \\
s. & $\begin{array}{l}\text { students, such as decreased } \\
\text { motivation, feelings of anxiety, } \\
\text { boredom, lack of enthusiasm, } \\
\text { 4. }\end{array}$ Becoming easily bored and overthinking & more laziness, dullness, and \\
5. & Becoming lazier and less excited because the culture at home is \\
different from when on campus & Being insecure when asking questions online & \\
\hline
\end{tabular}

The results of the data analysis found that students had various self-motivating techniques. The student's version of self-motivating methods is (1) interacting with family or close friends; (2) recognizing parents' struggles; (3) considering the cost of single tuition fees, which are not cheap; (4) watching motivational videos from YouTube; (5) exercising; (6) going out for a walk; (7) sing for a moment; (8) looking at the list of task deadlines; (9) doing light activities for a while, such as playing games; (10) reading books; (11) cleaning the house; (12) asking the progress of assignments from other friends; (13) do self-talk or private speech; (14) providing self-rewards for certain achievements. In numbers 1, 4, 5, $6,7,9,10$, and 11 are basic techniques with the basis of taking a moment to rest the brain, which is always focusing on tasks and learning or the other term is refreshing or the brain condition goes into diffuse mode. Meanwhile, numbers 2, 3, 8, 12, 13 related to their responsibility to complete the study, and number 14 is a trigger or stimulus for the students to complete the assignment.

\section{Physical condition}

Online learning during the Covid-19 pandemic caused physical fatigue in students. The results of the analysis of the physical condition of students can be seen in Table 6. Students' physical fatigue was triggered by reduced sports activities from students, reduced movement of students because they were constantly in front of gadgets, and too long exposure to blue light from gadget screens. The reduced movement made students started to feel back pain, pain in the neck and shoulder area.

Table 6. Reduction Results related to Physical Conditions

\begin{tabular}{cll}
\hline No. & Sub-theme & Correlation between Sub-theme \\
\hline 1. & The occurrence of eye fatigue & Online learning causes physical \\
2. & Experiencing back pain & fatigue in students, such as back and \\
3. & Experiencing pain in the neck area & neck pain, dizziness, eye fatigue, \\
4. & Becoming easily sleepy during online class & increased eye nearsightedness and \\
5. & Increased nearsightedness and astigmatism of the eyes & astigmatism, and easily drowsy \\
6. & Inflicting headaches (dizziness) & during class \\
\hline
\end{tabular}

Monotonous activity in front of a laptop or smartphone makes it easier for students to get sleepy. This is because students are often joining lectures while lying down. Furthermore, looking at the gadget screen for too long makes students sometimes feel dizzy, the appearance of eye fatigue, and inflicting nearsightedness and astigmatism. The results of the analysis of strategies for dealing with physical fatigue found that all students suggested taking breaks. Some students conveyed their resting techniques, i.e., by taking a nap, getting out of the house to see the distant scenery and greenery, or stopping doing assignments or studying activities.

\section{Condition of Signal reception and Gadget}

Data analysis results on the theme of signal reception conditions show that most students' signal reception conditions were good; however, if the power goes out or there is bad weather can weaken the signal reception or even lose the reception. An unstable internet condition is certainly disrupting online learning during the Covid-19 pandemic. Bad weather that interferes with signal reception is when it 
rains heavily or when winds add to it. Also, in mountainous areas or high areas, students who are in mountainous areas said that the signal conditions in these areas are less stable. Only signals from the Telkomsel provider or via $\mathrm{WiFi}$ can support lectures. The data reduction results related to the condition of signal reception and gadget are presented in table 7.

In poor signal conditions, students have several techniques at their disposal. The technique of minimizing a weak signal reception is by changing to another provider, looking for a place with a stronger reception, looking for a WiFi place such as in a cafe or a place where there is WiFi, and switching from WiFi to the internet from the phone provider or vice versa.

The condition of gadgets is also often disturbed when there is a power cut. Moreover, students with weak battery power from their laptops and smartphones cannot be used for longer without any electrical power from the charger when the battery is minimal. Then, some of the students' problems when learning online using video conferences were the microphone sound, which often had problems, ranging from unclear sound or not generating sound at all.

Table 7. Reduction Results related to Conditions of Signal Reception and Gadget

\begin{tabular}{|c|c|c|}
\hline No. & Sub-theme & Correlation between Sub-theme \\
\hline 1. & Unstable internet conditions interfere with the learning session & Unstable signal conditions due to \\
\hline 2. & $\begin{array}{l}\text { The signal reception condition is unstable because the house } \\
\text { is in a mountainous/high area. }\end{array}$ & $\begin{array}{l}\text { mountainous area residency, the } \\
\text { influence of the weather, and power }\end{array}$ \\
\hline 3. & $\begin{array}{l}\text { Internet speed becomes slow when it rains heavily or when } \\
\text { there is wind. }\end{array}$ & outages \\
\hline 4. & Power outages disrupted the internet network. & \\
\hline $\begin{array}{l}5 . \\
6 .\end{array}$ & $\begin{array}{l}\text { Power outages disrupted the learning process } \\
\text { Unclear microphone's voice or not working microphone } \\
\text { interfere with online learning with video conferencing. }\end{array}$ & $\begin{array}{l}\text { The condition of the gadget is disturbed } \\
\text { when there are power outages and the } \\
\text { interference of the audio device that is } \\
\text { being used during the learning process }\end{array}$ \\
\hline
\end{tabular}

Students' solution to deal with gadget problems was to replace gadgets from laptops to smartphones or vice versa. If the two devices owned cannot solve the technical problem, they would borrow the equipment from their parents or another family member. If the power goes out, then before the lecture, they will always fully charge their laptop and smartphone.

\section{Learning Environment Conditions}

The data analysis results on the conditions of the learning environment found several obstacles, as shown in Table 8. The findings indicate that the student learning environment conditions are sometimes still not supportive for online learning due to the emergence of distractions that occur in the environment during learning.

Table 8. Reduction Results related to the Conditions of the Learning Environment

\begin{tabular}{cll}
\hline No. & Sub-theme & Correlation between Sub-theme \\
\hline 1. & $\begin{array}{l}\text { Noises from vehicles, factories, and other noise interfere with } \\
\text { the concentration in studying }\end{array}$ & $\begin{array}{l}\text { The condition of the student learning } \\
\text { environment sometimes does not } \\
\text { support learning because of the } \\
\text { distraction that occurs in the } \\
\text { 2. A less calm environment due to interference from young } \\
\text { children interferes with learning. }\end{array}$ \\
3. There are distractions from smartphones such as the desire to & $\begin{array}{l}\text { environment } \\
\text { open YouTube, social media, read comics, et cetera }\end{array}$ \\
4. Off-campus work sometimes hinders learning.
\end{tabular}

In the environment's condition, some students felt disturbed by the noise generated from vehicles passing in front of the house, the noise from the wood factory, and the noise from airplanes. The commotion or noise pollution distracts students from being able to concentrate on studying. Besides, other students explained that the learning environment was often less calm due to interference from younger siblings or nephews. Then, often there were chores outside of campus assignments that sometimes hinder learning. The last thing was the distraction from gadgets such as the desire to open YouTube, social media, read comics, play games et cetera. Although sometimes these activities are to refresh the mind after doing assignments, however, if it cannot be controlled, it will hinder students learning process. 
Jurnal Prima Edukasia, 9 (2), 2021 - 241

Anang Fathoni, Heri Retnawati

The strategies that students use to reduce distraction that appear in the environment were (1) searching for a quiet and conducive place; (2) closing the room when doing assignments or studying to reduce interference from younger siblings or nephews; (3) disabling some annoying applications; and (4) spend time to study or doing assignments at night or even early morning.

\section{Activity Conditions in Learning}

Data analysis results on activity conditions in learning show that learning activities that occur in online learning were still not optimal during the Covid-19 pandemic. Ineffective group discussions marked the less optimal learning process during the Covid-19 pandemic. This was because the space for discussion and questions was limited. Students felt constrained when discussing the e-learning system or video conferences because students who can speak and express opinions were limited. Especially if the discussion process or expressing opinions became disturbed due to unstable signal reception conditions, students' words were incomplete and prone to miscommunication. Also, students felt that there were still lecturers who sometimes did not give clear instructions, which confused the learning process. Then, online learning made it more difficult for students to understand the explanation of the material. This was again due to the limited space for direct discussion, both between individuals and in groups. Besides, students also explained that the source of printed books was more difficult to find because it was constrained by not going directly to the library. Students conveyed that it felt incomplete to studying without a handbook as a learning resource. Finally, there were still students who openly stated to be constrained by time management.

Based on the obstacles that have been discovered in learning activities, students convey several strategies to overcome these problems. When getting unclear instructions, the student's strategy was to rediscuss it with other students in the WhatsApp group until the information was obvious. If clarity was still not acquired, then the head or person in charge of the course will immediately confirm it with the relevant lecturer. If there was unclear material or not very clear online learning, students would find out independently through an internet search engine, asking friends or directly asking related lecturers.

Furthermore, the strategy in dealing with not being able to go to the library was by searching for sources from (1) ebooks available on the internet; (2) Online libraries such as ipusnas, openlibrary.org or books.google.com; and (3) increasing the number of sources from journal articles. Then for time management, other students conveyed their strategies, particularly (1) making a priority scale in doing assignments; (2) creating a to-do list; (3) creating alarms for important activities; and (4) inventing a series of achievements that have been made.

\section{Potential arising in the future after the covid-19 pandemic may be controlled}

On the topic of the potential that appears in the future after the Covid-19 pandemic can be resolved from the student's point of view, two main points were obtained, particularly in teaching and learning activities and technology-based learning. Students convey that the potential that appears in teaching and learning activities is students' increased learning independence. This is because starting from the beginning of the emergence of Covid-19, students studied independently in their own boarding houses or homes for nearly a year. Also, teaching and learning activities can carry out a broader blended learning model, not only in tertiary institutions but also in elementary to high school. Furthermore, it opens the mindset of educators, students, and the wider community regarding learning that can be done anywhere and anytime. Moreover, at the point of technology-based learning, students conveyed the emerging potential, i.e. (1) developing an understanding of the importance of technology-based learning; (2) students and lecturers are more technology literate; (3) awareness of ICT skills increases; and (4) creating more innovative learning through the use of technology.

In addition to the potential that emerges in the future, there are also negative things that are a legacy of Covid-19 from those conveyed by students. The negative things left behind by Covid-19 after being resolved are (1) it takes time to re-adapt when everything returns to normal; (2) differences in the quality of knowledge when there was Covid-19 and after Covid-19 is resolved. The difference in question is that the capacity of knowledge obtained will be better before Covid-19 or after Covid-19 is resolved. This is because at the time of Covid-19, there were still many gaps in online learning carried out by educators, and there were still many shortcomings for students in their learning activities; (3) reduced public speaking skills; (4) ethical and attitude issues; and (5) reduced social interaction, as well as norms. 
Jurnal Prima Edukasia, 9 (2), 2021 - 242

Anang Fathoni, Heri Retnawati

\section{Discussion}

The first key for online learning can be carried out is fulfilling the facility's needs consisting of gadgets and the internet. Without this, online learning will not be possible. This is as conveyed by previous research that in addition to having educators and students, platforms that can be processed via gadgets and the internet must be fulfilled (Hamid et al., 2020; Zhu et al., 2020). Students are also accustomed to using technology in online learning both before and during the occurrence of Covid-19, with the intensity of use increasing after the emergence of Covid-19. This shows that the skills to use technology are extremely important in applying online learning, as stated in previous research (Arlinwibowo et al., 2020; Jan, 2015; Makawawa et al., 2021).

Besides, online learning makes students more independent in education and makes them manage study time with other activities. Previous research has shown that online learning provides students with independence in learning (Erarslan \& Arslan, 2020; Vahrusheva et al., 2020; Wahyuni, 2018). Then, the learning environment's support is influenced by three things, particularly the facilities owned, support from family, and a quiet and comfortable learning environment. This is following previous research that the facilities owned are in the form of gadgets and internet (Dabbagh, 2007; Jalinus \& Ambiyar, 2016; Zhu et al., 2020), family support (Mulyana et al., 2020; Sari, 2020), and a comfortable environment, including eliminating distractions in learning (Erarslan \& Arslan, 2020; Sadikin \& Hamidah, 2020) affect the success of the learning process.

Student activities in searching for a comfortable learning environment certainly grant students the ability to look for useful techniques in optimizing learning during the Covid-19 pandemic. These techniques were such as eliminating distraction from social media, providing rewards for self-achievement, creating reminders for mandatory activities, setting priority scales, adding to learning routines from YouTube and webinars, and carrying out a series of studies such as reading, rewriting, criticizing, elaboration of knowledge, shaping arguments and brainstorming.

A well-established student-lecturer relationship will help students in online learning, while a less strong student-lecturer relationship will hinder student learning. This is in line with previous findings that good communication between lecturers and students can increase engagement in learning (Zeng et al., 2016), reduce anxiety (Talidong \& Toquero, 2020), and build emotional patterns can provide cognitive support for students (Chatzara et al., 2016). Also, communication that is not well established or explanations that are not maximal from the lecturers will hinder students' online learning (Jariyah \& Tyastirin, 2020), including a lack of feedback from educators (Erarslan \& Arslan, 2020). Previous research also states that the existing interactions were also reduced, and material delivery becomes somewhat passive (Tartavulea et al., 2020). However, previous research also states that educators also expect students' involvement and feedback (Diningrat et al., 2020).

Then, data analysis results show that student research during the Covid-19 pandemic could not be carried out optimally and made students worried. This is certainly in line with previous research that students will be worried because of the uncertainty about the joint research/writing process with inadequate support from supervisors (Silinda \& Brubacher, 2016). Also, students stated that the signal reception conditions were not good due to the mountainous residency area, the influence of the weather, and power outages. Whereas poor signals reception was an obstacle to online learning, as has been conveyed in previous research (Alqurashi, 2019; Arlinwibowo et al., 2020; C. S. Chang et al., 2014; Diningrat et al., 2020; Noer et al., 2021; Octaberlina \& Muslimin, 2020). Furthermore, discussions held in class became more limited during the Covid-19 pandemic, even though previous research has shown that learning by discussion is an effective strategy in developing students' communication skills (Rosdianti et al., 2020).

Furthermore, online learning affects students' psychological conditions, such as decreased motivation, feelings of anxiety, boredom, lack of enthusiasm, laziness, dullness, and overthinking. This is in line with previous research that online learning causes stress ((Ghiasvand et al., 2017; Tseng et al., 2019), feelings of anxiety (Wang \& Zhao, 2020), laziness (Jhon et al., 2020), and feeling bored (Herliandry, Nurhasanah, Suban, \& Kuswanto, 2020). Besides, online learning also causes physical fatigue in students, such as back and neck pain, dizziness, eye fatigue, increased nearsightedness and astigmatism, and drowsiness during class. The eye fatigue case is in line with previous research, which found that online learning that continues to use gadgets can strain the eyes (Octaberlina \& Muslimin, 2020). 
Jurnal Prima Edukasia, 9 (2), 2021 - 243

Anang Fathoni, Heri Retnawati

However, the emergence of obstacles and negative impacts did not make students stand idle and yield to the situation. Through this situation, students were still looking for the most effective strategy or way to reduce all obstacles and negative impacts that arise from Covid-19. The student's strategy in dealing with psychological conditions was by reserving time for resting, refreshing, and communicating with friends. Students' strategy in dealing with tired physical conditions was by resting, adjusting the time spent in front of devices, and dimming the screen. Another strategy has been presented in the "student technique to optimize learning" in the previous paragraph.

Thus, the research results indicating that learning activities that occur in online learning are currently not optimal even though it has been operating for almost a year in Indonesia. Previous research supports this statement that the implementation of online learning during Covid-19 has not been fully effective (Hamid et al., 2020). This is because the shifting of the environment from face-to-face to a fully online environment is an uneasy new challenge (Scull et al., 2020), even though online learning is considered the most appropriate crisis response time (Murphy, 2020). The use of technology and information is the main key during the Covid-19 pandemic in education (Herliandry, Nurhasanah, Suban, \& Heru, 2020).

Then, the perspective of students in the future when the Covid-19 pandemic can be resolved is the emergence of potential and negative things being left behind from Covid-19 in the world of education. The potential that appears in teaching and learning activities is the increased independence of learning from students, the blended learning model adapted to a broader sector, opening the mindset of educators, students, and the wider community regarding learning that can be done anywhere and anytime, it develops the understanding of the importance of technology-based learning, students and lecturers are more technology literate, awareness of ICT skills increases and the emergence of more innovative learning with the use of technology. Previous research also shows the point of view of lecturers and students that still provide the chance to use online learning after Covid-19 can be resolved and for future curriculum (Schlenz et al., 2020).

Also, the negative legacy after Covid-19 has been resolved, particularly the need for time to adapt when everything returns to normal, differences in the quality of knowledge during Covid-19 occurrence and after Covid-19 is resolved, public speaking skills are reduced, ethical issues and attitudes, and social interactions are reduced, and so are norms. The conditions that have been previously stated are undoubtedly relevant to the point of view of other researchers that the emergence of inequality in the quality of education (Thomas \& Rogers, 2020), and the emergence of problems in the moral sphere (Smith \& Upshur, 2020). This certainly needs to be the educators' attention from now on as preparation for facing new learning after Covid-19 has been resolved. In-depth research is still needed regarding learning during the Covid-19 pandemic. Seeing the possibilities that arise after the Covid-19 pandemic can be overcome and deal with it from an educational perspective.

\section{Conclusion}

Based on the results of data analysis, general conclusions were obtained in this Study as follows. First, students had varied experiences throughout online learning during the Covid-19 pandemic. Second, students acquired negative physical and psychological impacts, acquired obstacles to signal reception, gadgets, interaction with lecturers, independent study, and learning activities during the Covid-19 pandemic. Third, students had various strategies in dealing with the obstacles and negative impacts of Covid-19. Fourth, online learning during the Covid-19 pandemic were leaving potential as well as negative things in the future after it is resolved.

Specific conclusions in this study are (1) students were accustomed to using technology in online learning with an increasing intensity of use after the emergence of Covid-19; (2) online learning made students more independent in learning and encouraged students to manage their time in learning and other activities that arise while learning from home; (3) support for the learning environment in online learning was influenced by three things, specifically the facilities owned, support from family and a calm and comfortable learning environment; (4) students had a variety of techniques in optimizing learning during the pandemic; (5) a good relationship between students and lecturers will help students in online learning, while a less well-established relationship will prevent students from learning online; (6) students' research during the Covid-19 Pandemic could not be carried out optimally and made students worried; (7) students had negative psychological and physical impacts when learning online; 
Jurnal Prima Edukasia, 9 (2), 2021 - 244

Anang Fathoni, Heri Retnawati

(8) students experienced interference with signal reception and gadgets when the weather was not good, there was power otages or houses reside in mountainous or highlands; (9) a noisy learning environment disturbed student concentration; (10) learning activities during the Covid-19 pandemic were deemed less than optimal.

To overcome the various problems experienced by postgraduate students in online learning, lecturers or the campus need to provide a forum for joint discussions between lecturers and students to open up to each other and find solutions to all obstacles and negative impacts that arise. Students also need to share effective strategies or techniques in independent learning during the Covid-19 pandemic by using video conferences either through google meet or zoom. Then, lecturers need to be more responsive, patient, and reflective in guiding students. Ultimately, campuses need to facilitate webinars related to effective learning during the Covid-19 pandemic for lecturers and students.

There are limitations in this study and suggestions for further research, specifically (1) this research is limited to direct observation because all activities are carried out online during the Covid-19 pandemic. Researchers have not been able to see firsthand the problems that occur in the field; therefore, there is a need for more in-depth research related to this matter; (2) this study has not explored the lecturers' perspectives on the obstacles, negative impacts, and strategies of the lecturers in online learning. Researchers have not been able to conduct in-depth interviews with lecturers regarding online learning during the Covid-19 pandemic, thus further research is needed that explores online learning from a lecturer perspective; (3) this research has not examined in depth the effective learning process during the Covid-19 pandemic; hence further research is needed regarding the effective online learning process during the Covid-19 pandemic.

\section{References}

Alqurashi, E. (2019). Predicting student satisfaction and perceived learning within online learning environments. Distance Education, 40(1), 133-148. https://doi.org/10.1080/01587919.2018.1553562

Arizona, K., Abidin, Z., \& Rumansyah, R. (2020). Pembelajaran online berbasis proyek salah satu solusi kegiatan belajar mengajar di tengah pandemi Covid-19. Jurnal Ilmiah Profesi Pendidikan, 5(1), 64-70. https://doi.org/10.29303/jipp.v5i1.111

Arlinwibowo, J., Retnawati, H., Kartowagiran, B., \& Kassymova, G. K. (2020). Distance learning policy in Indonesia for facing pandemic COVID-19: School reaction and lesson plans. Journal of Theoretical and Applied Information Technology, 98(14), 2828-2838.

https://pesquisa.bvsalud.org/global-literature-on-novel-coronavirus-2019ncov/resource/pt/covidwho-822222

Best, B., \& Conceição, S. C. O. (2017). Transactional distance dialogic interactions and student satisfaction in a multi-institutional blended learning environment. European Journal of Open, Distance and E-Learning, 20(1), 139-153. https://doi.org/10.1515/eurodl-2017-0009

Bogdan, R., \& Biklen, S. K. (1982). Qualitative research for education: An introduction to theory and methods. Allyn and Bacon.

Budiansyah, A. (2020, April). Internet digratiskan selama wabah corona di RI, setuju? CNBC Indonesia. https://www.cnbcindonesia.com/tech/20200407180620-37-150401/internetdigratiskan-selama-wabah-corona-di-ri-setuju

Cao, Y., \& Sakchutchawan, S. (2011). Online vs. traditional MBA: An empirical study of students' characteristics, course satisfaction, and overall success. The Journal of Human Resource and Adult Learning, 7(2), 1-12. http://www.hraljournal.com/Page/1 Yingxia Cao.pdf

Chang, C.-L., \& Fang, M. (2020). E-learning and online instructions of higher education during the 2019 novel coronavirus diseases (COVID-19) epidemic. Journal of Physics: Conference Series, 1574(1), 012166. https://doi.org/10.1088/1742-6596/1574/1/012166

Chang, C. S., Liu, E. Z. F., Sung, H. Y., Lin, C. H., Chen, N. S., \& Cheng, S. S. (2014). Effects of online college student's Internet self-efficacy on learning motivation and performance.

Innovations in Education and Teaching International, 51(4), 366-377.

https://doi.org/10.1080/14703297.2013.771429 
Chatzara, K., Karagiannidis, C., \& Stamatis, D. (2016). Cognitive support embedded in self-regulated e-learning systems for students with special learning needs. Education and Information Technologies, 21(2), 283-299. https://doi.org/10.1007/s10639-014-9320-1

Dabbagh, N. (2007). The online learner: Characteristics and pedagogical implications. Contemporary Issues in Technology and Teacher Education, 7(3), 217-226. https://citejournal.org/wpcontent/uploads/2014/05/v7i3general1.pdf

Daniel, S. J. (2020). Education and the COVID-19 pandemic. PROSPECTS, 49(1-2), 91-96. https://doi.org/10.1007/s11125-020-09464-3

Diningrat, S. W. M., Nindya, M. A., \& Salwa. (2020). Emergency online teaching: Early childhood education lecturers' perception of barrier and pedagogical competency. Cakrawala Pendidikan, 39(3), 705-719. https://doi.org/10.21831/cp.v39i3.32304

Duan, L., \& Zhu, G. (2020). Psychological interventions for people affected by the COVID-19 epidemic. The Lancet Psychiatry, 7(4), 300-302. https://doi.org/10.1016/S2215-0366(20)300730

Erarslan, A., \& Arslan, A. (2020). Online learning experiences of university students in ELT and the effects of online learning on their learning practices. Language and Technology, 2(1), 44-58. https://dergipark.org.tr/en/download/article-file/1138614

Ghiasvand, A. M., Naderi, M., Tafreshi, M. Z., Ahmadi, F., \& Hosseini, M. (2017). Relationship between time management skills and anxiety and academic motivation of nursing students in Tehran. Electronic Physician, 9(1), 3678-3684. https://doi.org/10.19082/3678

Hamid, R., Sentryo, I., \& Hasan, S. (2020). Online learning and its problems in the Covid-19 emergency period. Jurnal Prima Edukasia, 8(1), 86-95. https://doi.org/10.21831/jpe.v8i1.32165

Herliandry, L. D., Nurhasanah, N., Suban, M. E., \& Kuswanto, H. (2020). Pembelajaran pada masa pandemi Covid-19. JTP - Jurnal Teknologi Pendidikan, 22(1), 65-70. https://doi.org/10.21009/jtp.v22i1.15286

Herliandry, L. D., Nurhasanah, Suban, M. E., \& Heru, K. (2020). Pandemic learning during the Covid19. Jurnal Teknologi Pendidikan, 22(1), 65-70. https://doi.org/10. 21009/jtp.v22i1.15286

Jalinus, N., \& Ambiyar, A. (2016). Media dan sumber pembelajaran. Kencana.

Jan, S. K. (2015). The relationships between academic self-efficacy, computer self-efficacy, prior experience, and satisfaction with online learning. American Journal of Distance Education, 29(1), 30-40. https://doi.org/10.1080/08923647.2015.994366

Jariyah, I. A., \& Tyastirin, E. (2020). Proses dan kendala pembelajaran biologi di masa pandemi Covid-19: Analisis respon mahasiswa. Jurnal Penelitian Dan Pengkajian Ilmu Pendidikan: ESaintika, 4(2), 183. https://doi.org/10.36312/e-saintika.v4i2.224

Jhon, W., Mustadi, A., \& Zubaidah, E. (2020). Online learning during Covid-19 pandemic in developing countries: Does it run well? Jurnal Pendidikan Progresif, 10(3), 440-454. https://doi.org/10.23960/jpp.v10.i3.202005

Lee, A. (2020). Wuhan novel coronavirus (COVID-19): why global control is challenging? Public Health, 179, 19-21. https://doi.org/10.1016/j.puhe.2020.02.001

Makawawa, J. C., Mustadi, A., Septriwanto, J. Van, Sampouw, F., \& Najoan, R. A. O. (2021). Primary school teachers perception of technological pedagogical content knowledge in online learning due to Covid 19. Jurnal Prima Edukasia, 9(1), 86-96. https://doi.org/10.21831/jpe.v9i1.35245

Menteri Pendidikan dan Kebudayaan RI. (2020). Surat edaran nomor 4 tahun 2020 tentang pelaksanaan kebijakan pendidikan dalam masa darurat penyebaran coronavirus disease (Covid19).

Mulawarman, W. G. (2020). Persoalan dosen dan mahasiswa masa pandemik Covid 19: Dari gagap teknologi hingga mengeluh boros paket data. Prosiding Seminar Nasional Hardiknas, 1, 37-45. http://proceedings.ideaspublishing.co.id/index.php/hardiknas/article/view/6

Mulyana, M., Rainanto, B. H., Astrini, D., \& Puspitasari, R. (2020). Persepsi mahasiswa atas penggunaan aplikasi perkuliahan daring saat wabah Covid-19. JAS-PT (Jurnal Analisis Sistem 
Jurnal Prima Edukasia, 9 (2), 2021 - 246

Anang Fathoni, Heri Retnawati

Pendidikan Tinggi Indonesia), 4(1), 47. https://doi.org/10.36339/jaspt.v4i1.301

Murphy, M. P. A. (2020). COVID-19 and emergency eLearning: Consequences of the securitization of higher education for post-pandemic pedagogy. Contemporary Security Policy, 41(3), 492-505. https://doi.org/10.1080/13523260.2020.1761749

Noer, R. Z., Al Wahid, S. M., \& Febriyanti, R. (2021). Online lectures: An implementation of full elearning action research. Jurnal Prima Edukasia, 9(1). https://doi.org/10.21831/jpe.v9i1.35030

Octaberlina, L. R., \& Muslimin, A. I. (2020). EFL students perspective towards online learning barriers and alternatives using moodle/google classroom during COVID-19 pandemic. International Journal of Higher Education, 9(6), 1. https://doi.org/10.5430/ijhe.v9n6p1

Oktavian, R., \& Aldya, R. F. (2020). Efektivitas pembelajaran daring terintegrasi di era pendidikan 4.0. Didaktis: Jurnal Pendidikan Dan Ilmu Pengetahuan, 20(2), 129-135. https://doi.org/10.30651/didaktis.v20i2.4763

Pratiwi, H. (2019). Komitmen mengajar. Andi Offset.

Purwanto, A., Pramono, R., Asbari, M., Hyun, C. C., Wijayanti, L. M., \& Putri, R. S. (2020). Studi eksploratif dampak pandemi COVID-19 terhadap proses pembelajaran online di sekolah dasar. EduPsyCouns: Journal of Education, Psychology and Counseling, 2(1), 1-12. https://ummaspul.e-journal.id/Edupsycouns/article/view/397

Rakhmanov, O., \& Dane, S. (2020). Knowledge and anxiety levels of african university students against COVID-19 during the pandemic outbreak by an online survey. Journal of Research in Medical and Dental Science, 8(3), 53-56. https://pesquisa.bvsalud.org/global-literature-onnovel-coronavirus-2019-ncov/resource/pt/covidwho-689028

Rosdianti, H., Wuryandani, W., \& Retnawati, H. (2020). Teachers' strategies in developing and measuring students' communication skills. Al Ibtida: Jurnal Pendidikan Guru MI, 7(2), 237. https://doi.org/10.24235/al.ibtida.snj.v7i2.6836

Sadikin, A., \& Hamidah, A. (2020). Pembelajaran daring di tengah wabah Covid-19. BIODIK, 6(2), 109-119. https://doi.org/10.22437/bio.v6i2.9759

Sari, T. T. (2020). Self-efficacy dan dukungan keluarga dalam keberhasilan belajar dari rumah di masa pandemi Covid-19. Education Journal : Journal Educational Research and Development, 4(2), 127-136. https://doi.org/10.31537/ej.v4i2.346

Satuan Tugas Penanganan COVID-19. (2020). Data sebaran Covid-19. Covid19.Go.Id.

Schlenz, M. A., Schmidt, A., Wöstmann, B., Krämer, N., \& Schulz-Weidner, N. (2020). Students' and lecturers' perspective on the implementation of online learning in dental education due to SARSCoV-2 (COVID-19): A cross-sectional study. BMC Medical Education, 20(1), 1-7. https://doi.org/10.1186/s12909-020-02266-3

Scull, J., Phillips, M., Sharma, U., \& Garnier, K. (2020). Innovations in teacher education at the time of COVID19: an Australian perspective. Journal of Education for Teaching, 00(00), 1-10. https://doi.org/10.1080/02607476.2020.1802701

Silinda, F. T., \& Brubacher, M. (2016). Distance learning postgraduate student stress while writing a dissertation or thesis. International Journal of E-Learning \& Distance Education, 31(1), 1-14. http://www.ijede.ca/index.php/jde/article/view/958

Smith, M. J., \& Upshur, R. E. G. (2020). Learning lessons from COVID-19 requires recognizing moral failures. Journal of Bioethical Inquiry, 17(4), 563-566. https://doi.org/10.1007/s11673020-10019-6

Sudarsana, I. K., Lestari, N. G. A. M. Y., Wijaya, I. K. W. B., Krisdayanthi, A., Andayani, K. Y., Trisnadewi, K., Muliani, N. M., Dewi, N. P. S., Suparya, I. K., Gunawan, I. G. D., Kusumawati, N. A., Purandina, I. P. Y., Sutriyanti, N. K., Sudiani, N. N., Adnyani, N. W., Iragraha, S. M. F., Winaya, I. M. A., Siswadi, G. A., \& Aryana, I. M. P. (2020). COVID-19: Perspektif pendidikan. Yayasan Kita Menulis.

Suparman, M. A. (2014). Desain instruksional modern: Panduan para pengajar \& inovator pendidikan. Erlangga.

Syah, R. H. (2020). Dampak Covid-19 pada pendidikan di Indonesia: Sekolah, keterampilan, dan 
Jurnal Prima Edukasia, 9 (2), 2021 - 247

Anang Fathoni, Heri Retnawati

proses pembelajaran. SALAM: Jurnal Sosial Dan Budaya Syar-I, 7(5).

https://doi.org/10.15408/sjsbs.v7i5.15314

Talidong, K. J. B., \& Toquero, C. M. D. (2020). Philippine teachers' practices to deal with anxiety amid COVID-19. Journal of Loss and Trauma, 25(6-7), 573-579.

https://doi.org/10.1080/15325024.2020.1759225

Tartavulea, C. V., Albu, C. N., Albu, N., Dieaconescu, R. I., \& Petre, S. (2020). Online teaching practices and the effectiveness of the educational process in the wake of the Covid-19 pandemic. Amfiteatru Economic, 22(55), 920-936. https://doi.org/10.24818/EA/2020/55/920

Thomas, M. S. C., \& Rogers, C. (2020). Education, the science of learning, and the COVID-19 crisis. PROSPECTS, 49(1-2), 87-90. https://doi.org/10.1007/s11125-020-09468-z

Tichavsky, L. P., Hunt, A., Driscoll, A., \& Jicha, K. (2015). "It's just nice having a real teacher": Student perceptions of online versus face-to-face instruction. International Journal for the Scholarship of Teaching and Learning, 9(2), 1-8. https://doi.org/10.20429/ijsotl.2015.090202

Tomes, J. L., Wasylkiw, L., \& Mockler, B. (2011). Studying for success: Diaries of students' study behaviours. Educational Research and Evaluation, 17(1), 1-12. https://doi.org/10.1080/13803611.2011.563087

Tseng, H., Yeh, H. Te, \& Tang, Y. (2019). A close look at trust among team members in online learning communities. International Journal of Distance Education Technologies, 17(1), 52-65. https://doi.org/10.4018/IJDET.2019010104

Vahrusheva, S. N., Masharova, T. V., \& Punchyk, V. (2020). The development of students' independence in the conditions of distance learning. SHS Web of Conferences, 79(17), 01009. https://doi.org/10.1051/shsconf/20207901009

Wahyuni, E. (2018). Improving studentsr independence and collaboration with blended learning. Proceedings of the 5th International Conference on Community Development (AMCA 2018), 231, 613-616. https://doi.org/10.2991/amca-18.2018.170

Wang, C., \& Zhao, H. (2020). The impact of COVID-19 on anxiety in Chinese University students. Frontiers in Psychology, 11(May), 1-8. https://doi.org/10.3389/fpsyg.2020.01168

World Health Organization. (2020). WHO Coronavirus Disease (COVID-19) dashboard. WHO. https://covid19.who.int/

Yuliani, M., Simarmata, J., Susanti, S. S., Mahawati, E., Sudra, R. I., Dwiyanto, H., Irawan, E., Ardiana, D. putu Y., Muttaqin, M., \& Yuniwati, I. (2020). Pembelajaran daring untuk pendidikan: Teori dan penerapan. Yayasan Kita Menulis.

Zeng, G., Hou, H., \& Peng, K. (2016). Effect of growth mindset on school engagement and psychological well-being of Chinese primary and middle school students: The mediating role of resilience. Frontiers in Psychology, 7(NOV), 1-8. https://doi.org/10.3389/fpsyg.2016.01873

Zhu, X.-R., Bei, Y.-L., \& Qiao, S. (2020). An analysis of online teaching reform of college teachers under the background of Covid-19 epidemic-Taking advanced mathematics teaching as an example. DEStech Transactions on Social Science, Education and Human Science, eelss, 113117. https://doi.org/10.12783/dtssehs/eelss2020/34601 